\title{
Human Bone Marrow Lymphocytes
}

\section{DISTRIBUTION OF LYMPHOCYTE SUBPOPULATIONS IN THE BONE MARROW OF NORMAL INDIVIDUALS}

\author{
ANThony S. FaUcI \\ From the Laboratory of Clinical Investigation, National Institute of Allergy \\ and Infectious Diseases, National Institutes of Health, \\ Bethesda, Maryland 20014
}

A в S T R ACT This study was undertaken to determine the proportions and in vitro immune capacities of lymphocyte populations in the bone marrows of normal humans. Relatively pure mononuclear cell suspensions were obtained from bone marrow aspirates by linear sucrose gradient centrifugations. Simultaneous peripheral blood and bone marrow specimens from each individual were assayed for lymphocyte surface markers and mitogen responsiveness. Maximal possible contamination of bone marrow aspirates by peripheral blood was determined by performing aspirates on individuals who had received ${ }^{51}$ chromium-labeled autologous erythrocytes. Thymus-derived ( $\mathrm{T}$ ) lymphocytes, as determined by the sheep red blood cell (E) rosette assay, comprised 8.6$( \pm 1.6) \%$ of the total bone marrow lymphocyte pool. Bone marrow-derived (B) lymphocytes, as determined by the presence of a complement receptor, made up 15.4$( \pm 1.9) \%$ of the lymphocyte pool whereas $74.6( \pm 2.4) \%$ of mononuclear cells lacked easily detectable surface markers. These findings could not be explained by contamination with peripheral blood lymphocytes since contamination was corrected for in the calculations. Lymphocyte-enriched suspensions of bone marrow cells responded to stimulation with phytohemagglutinin, concanavalin $\mathrm{A}$, and particularly pokeweed mitogen. In vitro incubations of bone marrow and peripheral blood lymphocytes with tritiated thymidine followed by determinations of $\mathrm{E}$ and erythrocyte antibody complement (EAC) rosettes were performed. Simultaneous rosetteradioautographs demonstrated that the proliferative potential of bone marrow $B$ lymphocytes was greater than peripheral blood B lymphocytes $(P<0.01)$. On the other hand, the proliferative potential of bone marrow $\mathrm{T}$

Received for publication 31 December 1974 and in revised form 12 March 1975. lymphocytes was the same as that of peripheral blood $T$ lymphocytes. These findings demonstrate that in addition to containing $\mathrm{B}$ lymphocytes the normal bone marrow contains a small fraction of $\mathrm{T}$ lymphocytes similar to the mature $\mathrm{T}$ lymphocyte pool found in the peripheral blood. These $T$ cells most probably enter the bone marrow parenchyma as part of the normal recirculating lymphocyte pool.

\section{INTRODUCTION}

It has been well-established in both animal species and man that the bone marrow $(B M)^{1}$ is the source of socalled BM-derived (B) lymphocytes (1). In the postnatal period, the $B M$ serves as the source of stem cells which, under the influence of the thymus, can differentiate into peripheral thymus-derived $(T)$ lymphocytes $(1,2)$. Several animal studies have demonstrated that in addition to serving as a source of rapidly turning over B lymphocytes throughout life, the BM also contains a small but definite compartment of mature long-lived $\mathrm{T}$ lymphocytes $(3,4)$. These cells are recirculating $\mathrm{T}$ lymphocytes which probably do not arise in the BM but enter from the circulation and are part of the larger total body recirculating lymphocyte pool which includes the thoracic duct lymph, spleen, and

${ }^{1}$ Abbreviations used in this paper: $\mathrm{B}$, bone marrow derived; $\mathrm{BM}$, bone marrow; $\mathrm{C}$, complement; Con $\mathrm{A}$, concanavalin A; E, erythrocyte; EA, erythrocyte antibody; EAC, erythrocyte antibody complement; FCS, fetal calf serum; HBSS, Hank's balanced salt solution; ${ }^{3} \mathrm{HTdR}$, tritiated thymidine; MEM-S, Eagle's minimum essential media; $\mathrm{PB}$, peripheral blood; $\mathrm{PBS}$, phosphate-buffered saline; PHA, phytohemagglutinin; PWM, pokeweed mitogen; RBC, red blood cells; SRBC, sheep red blood cells; $T$, thymus derived. 
lymph nodes $(5,6)$. In addition, mature $\mathrm{T}$ lymphocyte functions have been demonstrated in the $\mathrm{BM}$ in various animal studies. These include the ability to respond to T-cell mitogens $(7,8)$, to various antigens (9) including alloantigens (10), and the ability to mediate contact sensitivity (11) as well as the graft versus host reaction $(12,13)$. On the other hand, there have been conflicting data regarding the presence of a fraction of mature T lymphocytes in human BM. Some studies have found an absence of or minimal $T$ lymphocytes identified by surface markers and response to $T$ cell mitogens in the $\mathrm{BM}$ of patients with immunological deficiencies and some normal controls (14-17). Other studies, however, have demonstrated functionally mature $\mathrm{T}$ lymphocytes in the BM of children in long-term, chemotherapeutically induced remission from acute lymphoblastic leukemia (18-20). The present study was designed to examine $\mathrm{BM}$ aspirates from a large number of normal volunteers for the following purposes: to separate relatively pure populations of $\mathrm{BM}$ lymphocytes, to perform comparative studies done simultaneously on the peripheral blood ( $\mathrm{PB}$ ) and $\mathrm{BM}$ of each individual, to determine the maximal degree of contamination of $\mathrm{BM}$ specimens with $\mathrm{PB}$, to calculate the precise proportions of lymphocyte subpopulations contained within the BM parenchyma, and to characterize the relative proliferative potential of $\mathrm{PB}$ and $\mathrm{BM}$ lymphocyte subpopulations by simultaneous surface marker and radioautographic studies.

\section{METHODS}

Subjects. BM aspirates were done on 37 normal volunteers, 21 men and 16 women, ranging in age from 19 to 25 yr. Details of the procedure were explained to each individual, and informed consent was obtained. The subjects were all in excellent health and were taking no medications at the time of the study.

$B M$ aspirates. The site of the biopsy was the posterior superior iliac crest. The area was prepared with iodine and $75 \%$ alcohol and draped. Xylocaine (1\%) was used to anesthetize the overlying skin and periosteum. A Rosenthal needle was used and $0.5-1.0 \mathrm{ml}$ of aspirate was withdrawn into a syringe containing acid citrate anticoagulant. A "touch prep" smear was then done and only those specimens which contained macroscopically visible bone spicules and fat globules were used. Only one aspirate had to be rejected throughout the study. Each individual also had a 35- $\mathrm{ml}$ sample of heparinized peripheral blood drawn for comparative studies. Total nucleated cell counts were done on the BM aspirate as well as on a sample of $\mathrm{PB}$ using a Coulter counter (Model Fn, Coulter Electronics Inc., Fine Particle Group, Hialeah, Fla.). Differential counts (400 cells) on Wright-Giemsa stained smears were also done on both samples by the same observer throughout the study.

Determination of degree of contamination of $B M$ aspirate with $P B$. Despite the fact that meticulous attention was paid to avoiding gross contamination with $\mathrm{PB}$ as much as possible by withdrawing only $0.5-1.0 \mathrm{ml}$ of $\mathrm{BM}$ aspirate and accepting only those samples with visible bone spicules, further attempts were made to determine precisely the amount by volume of PB contained in aspirates drawn in this manner. It has been firmly established by radioactive labeling studies that nonnucleated $\mathrm{BM}$ erythrocytes (RBC) are intravascular (21). Hence, normal nonnucleated RBC contained in a $\mathrm{BM}$ marrow aspirate indicates contamination by $\mathrm{RBC}$ from $\mathrm{PB}$ contained in BM vascular channels. Eight subjects had BM aspirates obtained while they were partaking in an independent study in which they had been reinfused the previous day with radioactive chromium $\left({ }^{51} \mathrm{Cr}\right)$ autologous RBC. Simultaneous with the BM aspirate, a sample of $\mathrm{PB}$ was drawn and the radioactivity in equivalent volumes of $\mathrm{BM}$ and blood samples was compared to determine the percent contamination by volume of the BM samples with PB. Radioactivity was counted in an automatic gamma counter (Series 1185, Nuclear-Chicago, Des Plaines, Ill.).

Preparation of cell suspensions. BM cells were dispersed from the spicules by repeated aspirations through a $1-\mathrm{ml}$ pipette. RBC were removed from the aspirate by hypotonic lysis. Lymphocyte-rich suspensions were obtained from the BM aspirates by a modification of the sucrose gradient centrifugation method of Osmond (22). Briefly, five sucrose gradients of $15-35 \%$ (increments of $5 \%$ ) in Hank's balanced salt solution (HBSS) and $20 \%$ fetal calf serum (FCS) (Industrial Biological Labs., Inc., Rockville, Md.) were prepared. A gradient of $35 \%$ through $15 \%$ (2 $\mathrm{ml}$ of each $5 \%$ increment) was layered in a $1.5 \times 9-\mathrm{cm}$ plastic test tube to give a total of $10 \mathrm{ml}$. BM cells $\left(4 \times 10^{7}-2 \times 10^{8}\right)$ suspended in $2 \mathrm{ml}$ of Eagle's minimum essential media (MEM-S) (Grand Island Biological Co., Grand Island, N. Y.) were layered over the sucrose gradient and centrifuged at $100 \mathrm{~g}$ for $7 \mathrm{~min}$ at $20^{\circ} \mathrm{C}$. The upper $4.5 \mathrm{~cm}$ of the gradient containing the lymphocyte-rich suspension was collected, washed three times in MEM-S, and a cell count was performed in a Coulter counter (Coulter Electronics Inc.). A cytocentrifuge smear was made of the suspension and stained with Wright-Giemsa stain. A 400 cell differential count was performed by the same observer throughout the study. The lymphocyte-rich suspension from the upper portion of the sucrose gradient was used for subsequent studies except when indicated.

Mononuclear cells (lymphocytes and monocytes) were obtained from the 35-ml sample of heparinized PB (drawn at the time of the $\mathrm{BM}$ aspirate) by the Hypaque-Ficoll method (23).

Proportions of $T$ and $B$ lymphocytes. $T$ lymphocytes from lymphocyte-rich suspensions of $B M$ and $P B$ were identified by their ability to form spontaneous RBC (E) rosettes with sheep red blood cells (SRBC) (24). To 0.25 $\mathrm{ml}$ of the BM or PB mononuclear cell suspension $\left(4 \times 10^{6}\right.$ cells $/ \mathrm{ml}$ ) in HBSS was added $0.25 \mathrm{ml}$ of $0.5 \%$ SRBC. The mixed cell suspension was incubated at $37^{\circ} \mathrm{C}$ for $5 \mathrm{~min}$, centrifuged at $100 \mathrm{~g}$ for $5 \mathrm{~min}$ at $4^{\circ} \mathrm{C}$, and the supernatant HBSS was removed. $0.5 \mathrm{ml}$ of FCS which had been absorbed twice with SRBC was added, and the pellet was incubated at $4^{\circ} \mathrm{C}$ overnight. One-half the volume of supernate was then removed and the cells were gently resuspended by shaking. One drop of cell suspension was put on a glass slide and a coverslip applied. 200 lymphocytes were counted by the same observer throughout the study using phase contrast optics at $400 \times$ magnification on a Zeiss microscope (Carl Zeiss, Inc., New York). All lymphocytes binding more than three SRBC were considered positive.

$B$ lymphocytes were identified by their ability to bind antibody-complement coated SRBC (25). SRBC coated with rabbit IgM antibody (EA) were a gift from $\mathrm{Dr}$. 
Michael M. Frank and were prepared as previously described (26). Fresh mouse serum served as the source of complement (C). $1 \mathrm{ml}$ of mouse serum diluted $1: 10$ in veronal-buffered saline containing optimal concentrations of calcium and magnesium in $0.1 \%$ gelatin was incubated with $1 \mathrm{ml}$ of IgM EA $\left(1 \times 10^{8} / \mathrm{ml}\right.$ in phosphate-buffered saline [PBS]) for $40 \mathrm{~min}$ at $37^{\circ} \mathrm{C}$. The resulting EAC were washed three times in $0.01 \mathrm{M}$ EDTA-buffered saline and resuspended in $5 \mathrm{ml}$ of $0.01 \mathrm{M}$ EDTA-buffered saline. To $0.25 \mathrm{ml}$ of the EAC was added $0.25 \mathrm{ml}$ of the $\mathrm{BM}$ or $\mathrm{PB}$ lymphocyte suspension. The mixture was incubated on a rotator for $40 \mathrm{~min}$ at $37^{\circ} \mathrm{C}$. A drop of the suspension was placed on a glass slide and counted in the same manner as described above for $\mathrm{E}$ rosettes. Monocytes were distinguished from lymphocytes by morphology and by their phagocytosis of latex particles.

In addition to the EAC marker determination for $\mathrm{B}$ lymphocytes which was done in all subjects, 10 subjects had, in addition, determination of proportions of B lymphocytes in the BM and PB by Ig surface markers. Relative percentages of $\mathrm{B}$ lymphocytes in the $\mathrm{BM}$ and $\mathrm{PB}$ bearing surface $\operatorname{IgG}, \operatorname{IgM}$, and $\operatorname{IgA}$ were determined (27) using fluoresceinated goat antihuman $\operatorname{IgG}, \operatorname{IgM}$, and $\operatorname{IgA}$ antisera (Meloy Laboratories, Inc., Springfield, Va.). The specificity of these antisera was verified by immunoelectrophoresis and by blocking the staining by monospecific nonfluoresceinated anti-Ig. The lymphocyte suspensions were incubated separately with the various fluoresceinated anti-Ig for $45 \mathrm{~min}$ at $4^{\circ} \mathrm{C}$. The cells were then washed three times with cold PBS, resuspended in glycerol-PBS $(9: 1)$, and fluoresceinated cells were counted using a Zeiss fluorescent microscope with a HBO 200 mercury arc, a dichroic reflector 500, a 50 barrier filter, and a FITC 500 excitation filter.

Radioautographic studies of $B M$ and $P B$. The spontaneous synthesis of DNA by a cell indicates that the cell possesses proliferative capacity or the potential to divide under the proper conditions, since it is felt that DNA is synthesized by cells only in preparation for cell division (28-30). This measurement of spontaneous DNA synthesis has been employed to estimate the life span or state of maturation of cell populations (28-30). To determine the spontaneous DNA synthesis and hence the relative proliferative capacities of $T$ and $B$ lymphocytes in the $B M$ and $P B$, cell suspensions from eight subjects were incubated with tritiated thymidine $\left({ }^{3} \mathrm{HTdR}\right) \quad(6.7 \mathrm{Ci} / \mathrm{mM}$, New England Nuclear, Boston, Mass.) at a concentration of $100 \mu \mathrm{Ci} / \mathrm{ml}$ of cells for $1 \mathrm{~h}$ at $37^{\circ} \mathrm{C}$. Because of the difference in volumes of $\mathrm{BM}$ aspirates $(0.5-1.0 \mathrm{ml})$ and $\mathrm{PB}$ samples (35 $\mathrm{ml}$ ), the following was done: ${ }^{3} \mathrm{HTdR}$ was added to the unfractionated $\mathrm{BM}$ aspirate and incubated as described above. After the incubation, the cells were washed three times with MEM-S, and a smear of the unfractionated aspirate was made. The cells were then applied to a sucrose gradient as described above. $\mathrm{E}$ and erythrocyte antibody complement (EAC) rosettes were made separately from the lymphocyterich suspension, and cytocentrifuge smears were made of these rosetted lymphocytes which had previously been incubated with ${ }^{3} \mathrm{HTdR}$. For the PB sample, a 2-ml quantity of blood was incubated for $1 \mathrm{~h}$ with ${ }^{3} \mathrm{HTdR}$ as described above. The sample was then washed three times with MEM-S and smears made. For the simultaneous rosetteradioautograph studies on $\mathrm{PB}$, Hypaque-Ficoll separation was first performed on $30-\mathrm{ml}$ blood samples. The mononuclear layer was incubated with ${ }^{8} \mathrm{HTdR}$ for $1 \mathrm{~h}$, as described above, and E and EAC rosettes were prepared similar to the BM samples. The smears for radioautography were coated with Kodak NBT-2 emulsion (Eastman Kodak Co., Rochester, N. Y.), exposed in the dark at $4^{\circ} \mathrm{C}$ for 7 days, developed with Kodak D-19 (1:3 dilution), and stained with Giemsa. In radioautograph smears of unfractionated $\mathrm{BM}$ and $\mathrm{PB}$, as well as in radioautographs of $\mathrm{E}$ and $\mathrm{EAC}$ rosettes from fractionated $\mathrm{BM}$ and $\mathrm{PB}, 500$ cells were counted and cells containing 6-10 grains over their nuclei were considered weakly labeled, while cells containing greater than 10 nuclear grains were considered heavily labeled.

Lymphoid cells less than $8 \mu \mathrm{m}$ in diameter were called small lymphocytes and those greater than $8 \mu \mathrm{m}$ in diameter were called medium to large mononuclear cells.

Blastogenic response of $B M$ and $P B$ lymphocytes to mitogenic stimulation. $\mathrm{BM}$ and $\mathrm{PB}$ lymphocyte blastogenic responses to various mitogens were assayed separately but simultaneously for each subject. Sucrose gradient separated BM and Hypaque-Ficoll separated PB cells were suspended for culture in MEM-S supplemented with $0.02 \mathrm{M}$ L-glutamine, penicillin $100 \mathrm{U} / \mathrm{ml}$, streptomycin sulfate $100 \mu \mathrm{g} / \mathrm{ml}$, and $15 \%$ homologous $\mathrm{AB}$ serum (Antibodies Inc., Washington, D. C.). Cultures were done in microtiter plates (Cooke Laboratory Products, Cooke Engineering Co., Alexandria, Va.), as previously described (31). Each well contained $0.2 \mathrm{ml}$ of cells in a concentration of $0.5 \times 10^{6} \mathrm{lym}$ phocytes per ml. Quadruplicate cultures were incubated at $37^{\circ} \mathrm{C}$ in $5 \% \mathrm{CO}_{2}$ in air at $100 \%$ humidity. $10 \mu \mathrm{l}$ of mitogen at various concentrations were added to each well. The mitogens used were: phytohemagglutinin (PHA) MR 68, lot K 4402 (Wellcome Reagents, Ltd., Beckenham, England), dose response curve from 0.5 to $10 \mu \mathrm{g} / \mathrm{ml}$ of culture; concanavalin A (Con A), lot 5,299 (Nutritional Biochemicals Corp., Cleveland, Ohio), dose response curve from 10 to $250 \mu \mathrm{g} / \mathrm{ml}$ of culture; and pokeweed mitogen (PWM), lot 180,690 (Grand Island Biological Co., Grand Island, N. Y.), $20 \mu \mathrm{l}$ of a $1: 100,1: 10,1: 5$, or $1: 2$ dilution in distilled water per $0.2 \mathrm{ml}$ of culture. Optimal stimulation for both $\mathrm{BM}$ and $\mathrm{PB}$ lymphocytes was found at 3 days of culture for PHA and Con A and at 5 days for PWM. $4 \mathrm{~h}$ before harvesting, $0.4 \mu \mathrm{Ci}$ of ${ }^{3} \mathrm{HTdR}(6.7 \mathrm{Ci} / \mathrm{mM}$, New England Nuclear) was added to each well. The cells were collected from the wells onto fiberglass filters using a semiautomated microharvesting device. The filters were washed with $10 \%$ trichloracetic acid (TCA) and $95 \%$ ethanol and placed in $10 \mathrm{ml}$ of Aquasol ${ }^{\circledR}$ (New England Nuclear). The TCA-precipitable radioactivity was counted in a liquid scintillation counter (Model LS-350, Beckman Instruments, Inc., Fullerton, Calif.). The arithmetic mean of the cpm of quadruplicate cultures was determined and the degree of stimulation was expressed where indicated either as the difference in $\mathrm{cpm}$ per $10^{6}$ lymphocytes between stimulated and unstimulated (control) cultures $(\Delta \mathrm{cpm})$, or as the stimulation index which is the ratio of cpm of stimulated or experimental cultures to control cultures (E/C).

Mixing of autologous $P B$ with irradiated $B M$. To determine the maximal potential contribution of contaminating $\mathrm{PB}$ to the mitogen induced blastogenesis of BM lymphocytes, the following was done. In four subjects BM aspirates were performed. A volume of $\mathrm{PB}$ equal to the volume of BM aspirate was simultaneously drawn. The BM specimen was then irradiated with 10,000 rads from a ${ }^{80}$ cobalt source. The nonirradiated $\mathrm{PB}$ was added to the irradiated $\mathrm{BM}$ cells, and the mixture was fractionated over a sucrose gradient, as described above, and then cultured in the presence of various doses of PHA. Hence, any blastogenesis noted would result from the small number of nonirradiated 
PB lymphocytes in the irradiated BM specimen. Irradiated $\mathrm{BM}$ alone was run as a control.

Statistics. Statistical analysis of data was performed using Student's $t$ test (32).

\section{RESULTS}

Mononuclear cell-enriched BM suspensions prepared from sucrose gradients. Sucrose gradient centrifugation resulted in a relatively pure mononuclear cell suspension (Fig. 1). Morphologic classification of BM mononuclear cells is quite difficult, particularly in microscopy involving rosettes and/or radioautography. Therefore, mature small, medium, and large lymphocytes, monocytes, immature lymphocytes and monocytes, and mononuclear stem cells were grouped for convenience into the category of mononuclear cells to distinguish them from the granulocyte and erythrocyte series in various stages of maturation within the BM. Unfractionated $\mathrm{BM}$ contained a mean $( \pm \mathrm{SEM})$ of 14.2$( \pm 1.6) \%$ mononuclear cells. After sucrose gradient purification, cell suspensions from the upper layer of the gradient contained $69.8( \pm 2.2) \%$ mononuclear cells with a yield of $79.5( \pm 5.8) \%$ of the total mononuclear cells originally put on the gradient. The viability of cells after separation on sucrose gradients was always greater than $90 \%$. Compared to this sucrose gradient technique, the Hypaque-Ficoll method is relatively inadequate in obtaining purified mononuclear cell suspensions from $\mathrm{BM}$ aspirates. Such preparations consistently contain up to $75 \%$ contamination with nonmononuclear cells, particularly those of the early granulocytic series such as myelocytes and metamyelocytes.

Contamination of $B M$ aspirates with $P B$. The maximal percent contamination by volume of BM aspirates with $\mathrm{PB}$ in six subjects is shown in Table I. Despite

TABLE I

Maximal Contamination of $B M$ Aspirate with $P B^{*}$

\begin{tabular}{lccc}
\hline Subject & $\begin{array}{c}\text { cpm‡ per } \\
\text { ml BM }\end{array}$ & $\begin{array}{c}\text { cpm per } \\
\text { ml blood }\end{array}$ & $\begin{array}{c}\text { \% volume } \\
\text { contamination } \\
\text { of BM aspirate } \\
\text { with PB§ }\end{array}$ \\
\hline G. O. & 5 & 18 & 28 \\
B. W. & 11 & 15 & 73 \\
M. N. & 18 & 30 & 60 \\
S. N. & 26 & 39 & 67 \\
D. H. & 20 & 24 & 83 \\
A. P. & 23 & 24 & 96 \\
Mean & 17.2 & 25.0 & 67.8 \\
\pm SEM & \pm 3.2 & \pm 3.5 & \pm 9.5 \\
\hline
\end{tabular}

* BM aspirate performed simultaneously with drawing of PB in six subjects who had received ${ }^{51} \mathrm{Cr}$-labeled autologous $\mathrm{RBC}$. $\ddagger \mathrm{cpm}$ of samples minus background.

$\S \mathrm{cpm}$ per $\mathrm{ml} \mathrm{BM} / \mathrm{CPM}$ per $\mathrm{ml}$ blood $\times 100=\%$ volume contamination.
TABLE II

Relative Proportions of Ig-Bearing Lymphocytes in $B M$ and $P B$

\begin{tabular}{cccc}
\hline & \multicolumn{4}{c}{ Percent lymphocytes bearing surface Ig } \\
\cline { 2 - 4 } & IgG & IgM & IgA \\
\hline PB, $n=10^{*}$ & & & \\
Mean & 14.6 & 7.4 & 4.8 \\
Range & $6-21$ & $4-13$ & $0-9$ \\
ISEM & \pm 1.5 & \pm 0.9 & \pm 0.9 \\
BM, $n=10$ & & & \\
Mean & 5.7 & 15.4 & 2.3 \\
Range & $2-10$ & $7-24$ & $0-7$ \\
ISEM & \pm 0.8 & \pm 1.9 & \pm 0.7 \\
\hline
\end{tabular}

${ }^{*} n$ is number of subjects studied.

meticulous care in drawing no more than $0.5-1.0 \mathrm{ml}$ of $\mathrm{BM}$ aspirate, as well as demonstrating macroscopically visible bone spicules in each of the six aspirates, the samples were still contaminated with $67.8( \pm 9.5) \%$ by volume of $\mathrm{PB}$. Because the cell density of the BM samples is so much greater than that of $\mathrm{PB}$, the actual absolute number of mononuclear cells in the contaminating $\mathrm{PB}$ was only $1.1( \pm 0.2) \times 10^{6}$, whereas the absolute number of mononuclear cells in the BM sample was $9.7( \pm 1.5) \times 10^{6}$. Hence, when the number of mononuclear cells in the BM sample which were contributed by contaminating $\mathrm{PB}$ was divided by the total number of mononuclear cells in the BM sample for each specimen, the actual contamination of $\mathrm{BM}$ mononuclear cells with PB mononuclear cells was $13.7( \pm 3.8) \%$.

Proportions of Ig-bearing lymphocytes in BM and $P B$. The relative proportions of lymphocytes bearing surface $\operatorname{IgG}, \operatorname{IgM}$, and $\operatorname{IgA}$ markers in the $\mathrm{BM}$ and $\mathrm{PB}$ of 10 subjects are shown in Table II. Lymphocytes bearing surface IgG predominate in the $\mathrm{PB}$, while those bearing surface $\operatorname{IgM}$ predominate in the BM. There is only a small percentage of $\mathrm{IgA}$ bearing lymphocytes in the BM $(2.3[ \pm 0.7] \%)$.

Relative proportions of $T$ and $B$ lymphocytes as well as mononuclear cells without detectable surface markers in the $B M$. In attempting to determine as accurately as possible the proportions of BM lymphocyte populations, it was considered crucial that strict attention be paid to the contamination of the $\mathrm{BM}$ aspirate with $\mathrm{PB}$ lymphocytes since it was known from labeling studies (Table I) that an apparently adequate BM aspirate can be contaminated with up to $96 \%$ by volume of $\mathrm{PB}$. Hence, maximal $(100 \%)$ contamination by volume of $\mathrm{PB}$ was presumed in each of the BM aspirates. Simultaneous $\mathrm{E}$ and $\mathrm{EAC}$ rosette determinations were performed on $\mathrm{PB}$ and $\mathrm{BM}$ samples from 22 subjects. The mean $( \pm \mathrm{SEM}) \% \mathrm{E}$ and EAC rosette-forming lympho- 


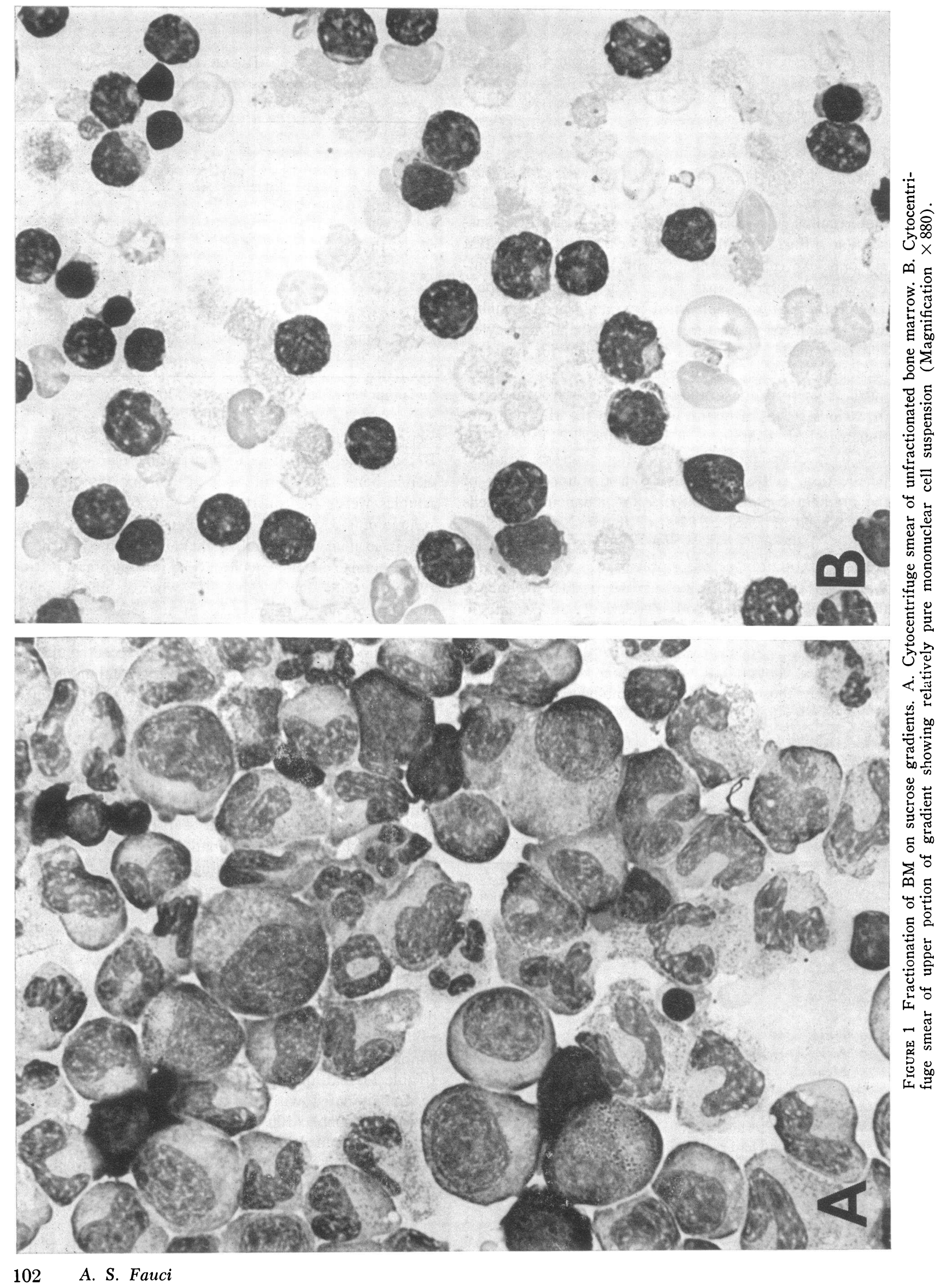


cytes in the PB were $69.0( \pm 2.3) \%$ and $19.3( \pm 1.0) \%$, respectively. The total number of $\mathrm{PB} E$ and $\mathrm{EAC}$ rosettes that could be contained in the volume of the $\mathrm{BM}$ aspirate in each individual was determined presuming maximal contamination by $\mathrm{PB}$. This number was subtracted from the total number of $\mathrm{E}$ and $\mathrm{EAC}$ rosettes in the $\mathrm{BM}$ sample, and then the percentage of $\mathrm{E}$ and $\mathrm{EAC}$ rosettes in the $\mathrm{BM}$ after "correction" for $\mathrm{PB}$ con-

TABLE III

Percentage of $T$ and $B$ Lymphocytes and Mononuclear Cells without Detectable Surface Markers in Normal Human BM*

\begin{tabular}{|c|c|c|c|}
\hline Subject & $\mathrm{T}$ cells $\ddagger$ & B cells§ & $\begin{array}{c}\text { Cells without } \\
\text { surface } \\
\text { markers } \|\end{array}$ \\
\hline & $\%$ & $\%$ & $\%$ \\
\hline 1 & 19 & 16 & 65 \\
\hline 2 & 9 & 8 & 83 \\
\hline 3 & 0 & 9 & 91 \\
\hline 4 & 16 & 10 & 74 \\
\hline 5 & 4 & 14 & 72 \\
\hline 6 & 2 & 25 & 73 \\
\hline 7 & 21 & 10 & 69 \\
\hline 8 & 10 & 8 & 82 \\
\hline 9 & 14 & 13 & 73 \\
\hline 10 & 3 & 11 & 86 \\
\hline 11 & 6 & 30 & 64 \\
\hline 12 & 10 & 21 & 69 \\
\hline 13 & 22 & 8 & 70 \\
\hline 14 & 3 & ND & - \\
\hline 15 & 6 & 30 & 64 \\
\hline 16 & 23 & 23 & 54 \\
\hline 17 & 0 & ND & - \\
\hline 18 & 0 & 26 & 74 \\
\hline 19 & 16 & ND & - \\
\hline 20 & 0 & ND & - \\
\hline 21 & 5 & 9 & 86 \\
\hline 22 & 0 & 7 & 93 \\
\hline Mean & 8.6 & 15.4 & 74.6 \\
\hline$\pm \mathrm{SEM}$ & \pm 1.7 & \pm 1.9 & \pm 2.4 \\
\hline
\end{tabular}

* Simultaneous determinations of total numbers of $\mathrm{T}$ and $\mathrm{B}$ lymphocytes in the $\mathrm{PB}$ and $\mathrm{BM}$ of each subject were performed. The maximal number of $\mathrm{PB} T$ and $\mathrm{B}$ lymphocytes which could possibly contaminate the volume of $\mathrm{BM}$ aspirate was determined and this amount was subtracted from the total number of $\mathrm{T}$ and $\mathrm{B}$ lymphocytes found in the $\mathrm{BM}$ aspirate. The percentages of $\mathrm{BM}$ T and $\mathrm{B}$ lymphocytes were then determined. Hence, the percentages shown are the minimal values based on correction for maximal contamination of $\mathrm{BM}$ aspirate by $\mathrm{PB}$.

I SRBC rosettes.

$\S$ EAC rosettes.

|| Mononuclear cells lacking easily detectable T- or B-cell surface markers.

I Not done.
TABLE IV

Percentage of Labeled $E$ and EAC Rosettes in $B M$ and $P B$

\begin{tabular}{|c|c|c|}
\hline & $\begin{array}{l}\% \text { of } E \\
\text { rosettes } \\
\text { labeled }\end{array}$ & $\begin{array}{c}\% \text { of EAC } \\
\text { rosettes } \\
\text { labeled }\end{array}$ \\
\hline \multicolumn{3}{|l|}{$\mathrm{BM}$} \\
\hline Subject 1 & 1.3 & 0.8 \\
\hline 2 & 0.3 & 1.0 \\
\hline 3 & 0.3 & 1.5 \\
\hline 4 & 0.8 & 1.5 \\
\hline 5 & 0.0 & 0.3 \\
\hline 6 & 0.5 & 1.7 \\
\hline 7 & 0.8 & 1.3 \\
\hline $\begin{array}{l}\text { Mean } \\
\pm \text { SEM }\end{array}$ & $\begin{array}{r}0.57 \\
\pm 0.16\end{array}$ & $\begin{array}{r}1.16 \\
\pm 0.19\end{array}$ \\
\hline \multicolumn{3}{|l|}{$\mathrm{PB}$} \\
\hline Subject 1 & 0.5 & 0.8 \\
\hline 2 & 0.5 & 0.3 \\
\hline 3 & 0.0 & 0.0 \\
\hline 4 & 0.3 & 0.0 \\
\hline 5 & 0.3 & 0.3 \\
\hline 6 & $\mathrm{ND}^{*}$ & ND \\
\hline 7 & ND & ND \\
\hline $\begin{array}{l}\text { Mean } \\
\pm \text { SEM }\end{array}$ & $\begin{array}{r}0.32 \ddagger \\
\pm 0.09\end{array}$ & $\begin{aligned} & 0.28 \S \\
\pm & 0.15\end{aligned}$ \\
\hline
\end{tabular}

* Not done.

$\ddagger$ No significant difference between $\mathrm{BM}$ and $\mathrm{PB}(P>0.2$, Student's $t$ test).

$\S$ Significant difference between $\mathrm{BM}$ and $\mathrm{PB}(P<0.01)$.

tamination was calculated. These relative proportions in the $\mathrm{BM}$ of $\mathrm{E}$ and $\mathrm{EAC}$ rosette-forming cells, as well as lymphoid cells without detectable surface markers, are shown in Table III.

Radioautographic studies in $B M$ and $P B$. In vitro incubation of $B M$ aspirates from 12 subjects for $1 \mathrm{~h}$ with ${ }^{3} \mathrm{HTdR}$ resulted in labeling of all cell types. After incubation of unfractionated $\mathrm{BM}$ with ${ }^{3} \mathrm{HTdR}$, mononuclear cells were separated on sucrose gradients and it was found that $14.9( \pm 2.3) \%$ of the mononuclear or lymphoid cells were heavily labeled. Almost all of these were medium to large sized cells.

After incubation of $\mathrm{PB}$ with ${ }^{3} \mathrm{HTdR}$ in seven subjects, no labeling of the granulocytic series was seen. Only $0.57( \pm 0.30) \%$ of the mononuclear or lymphoid cells in the $\mathrm{PB}$ were labeled. Of these, labeled small lymphocytes were not found, and only medium or large mononuclear cells were labeled. Most of these were heavily labeled.

To compare the potential for spontaneous proliferation of $\mathrm{T}$ and $\mathrm{B}$ lymphocytes in the $\mathrm{BM}$ and $\mathrm{PB}, \mathrm{E}$ and EAC rosette determinations were performed following incubation of $\mathrm{BM}$ or $\mathrm{PB}$ lymphoid cells with ${ }^{3} \mathrm{HTdR}$ and radioautographs were made (Fig. 2). Table IV lists 


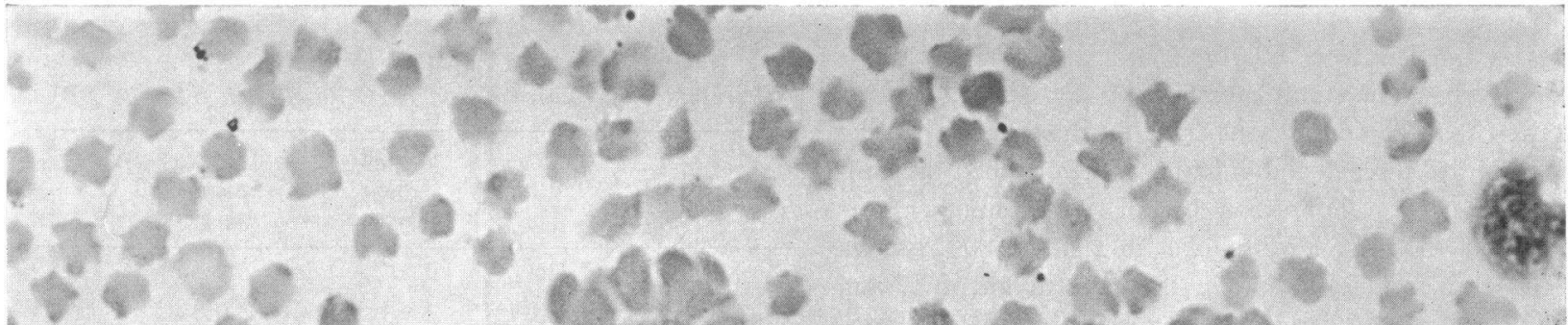

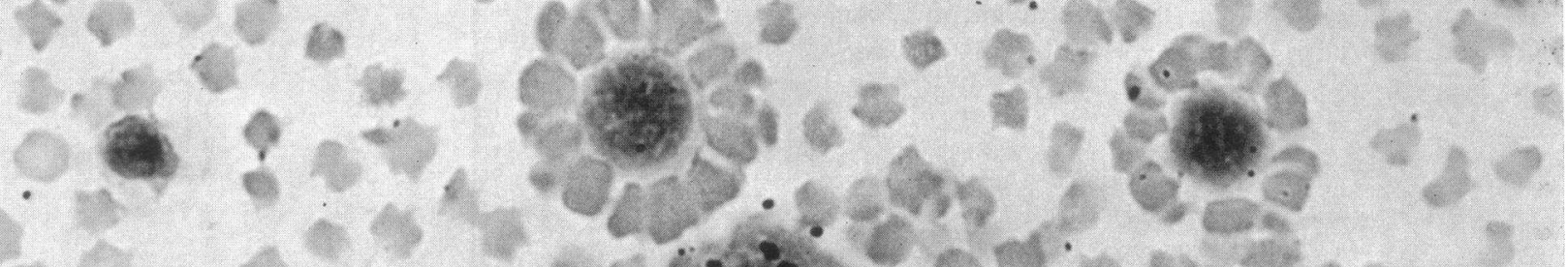
anto- ato

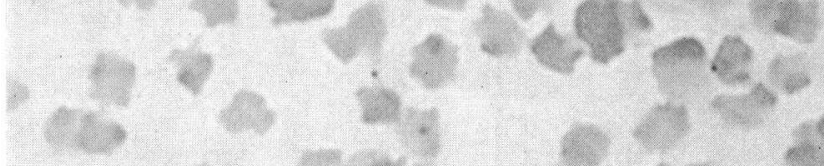

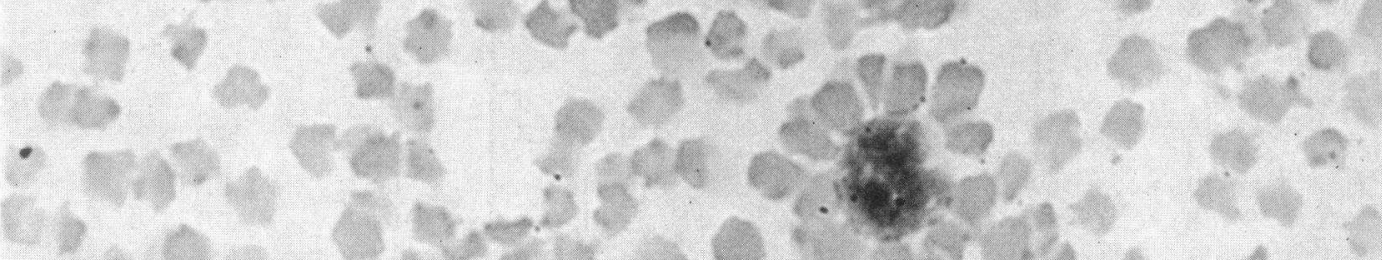

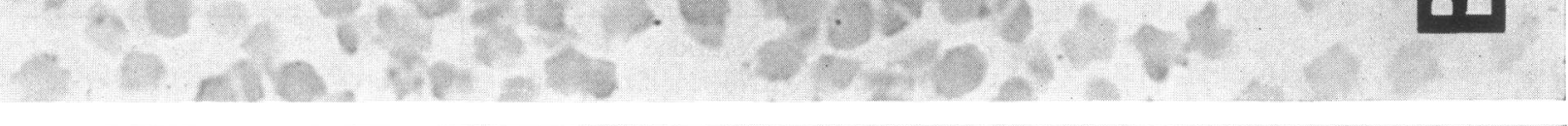

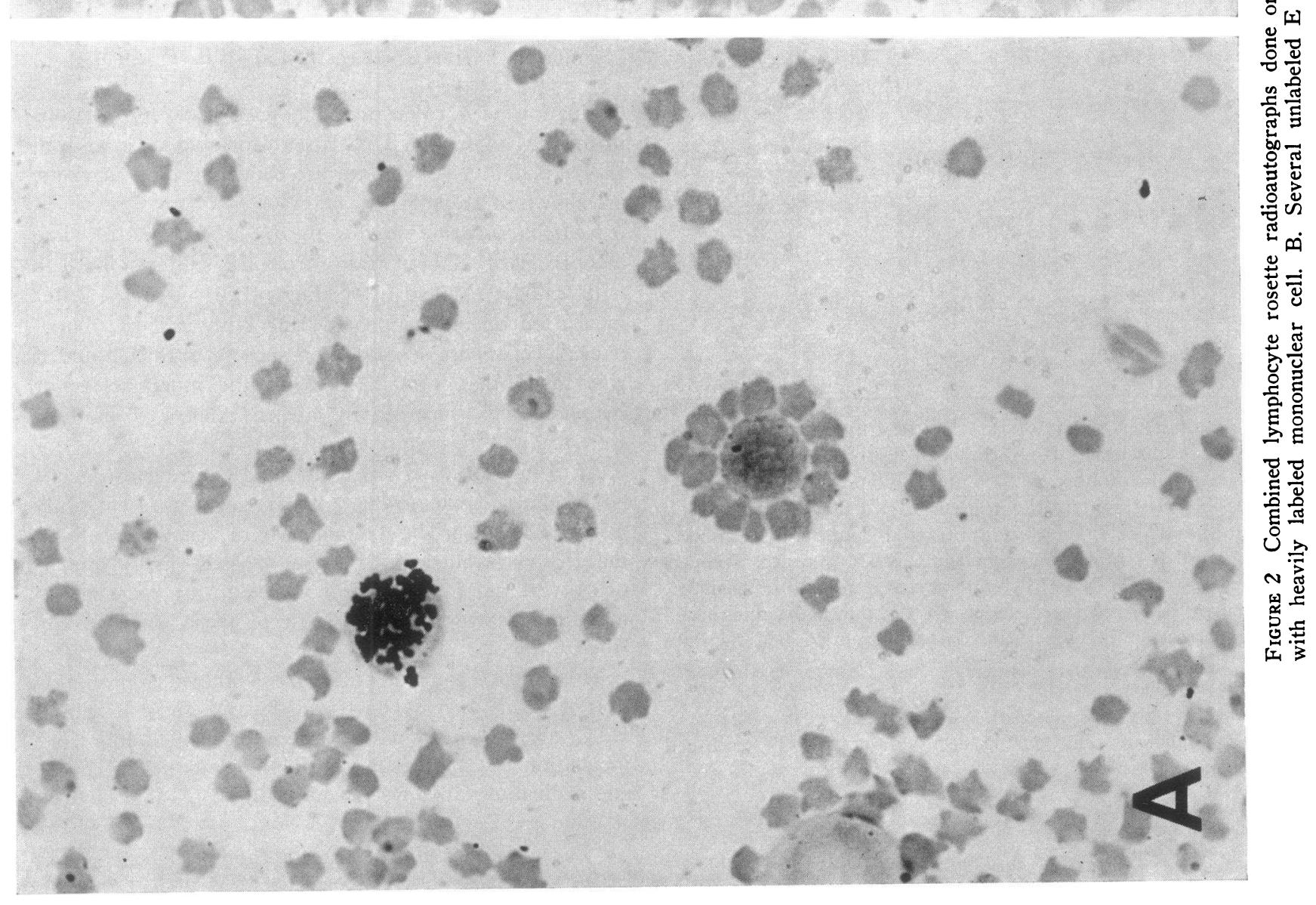




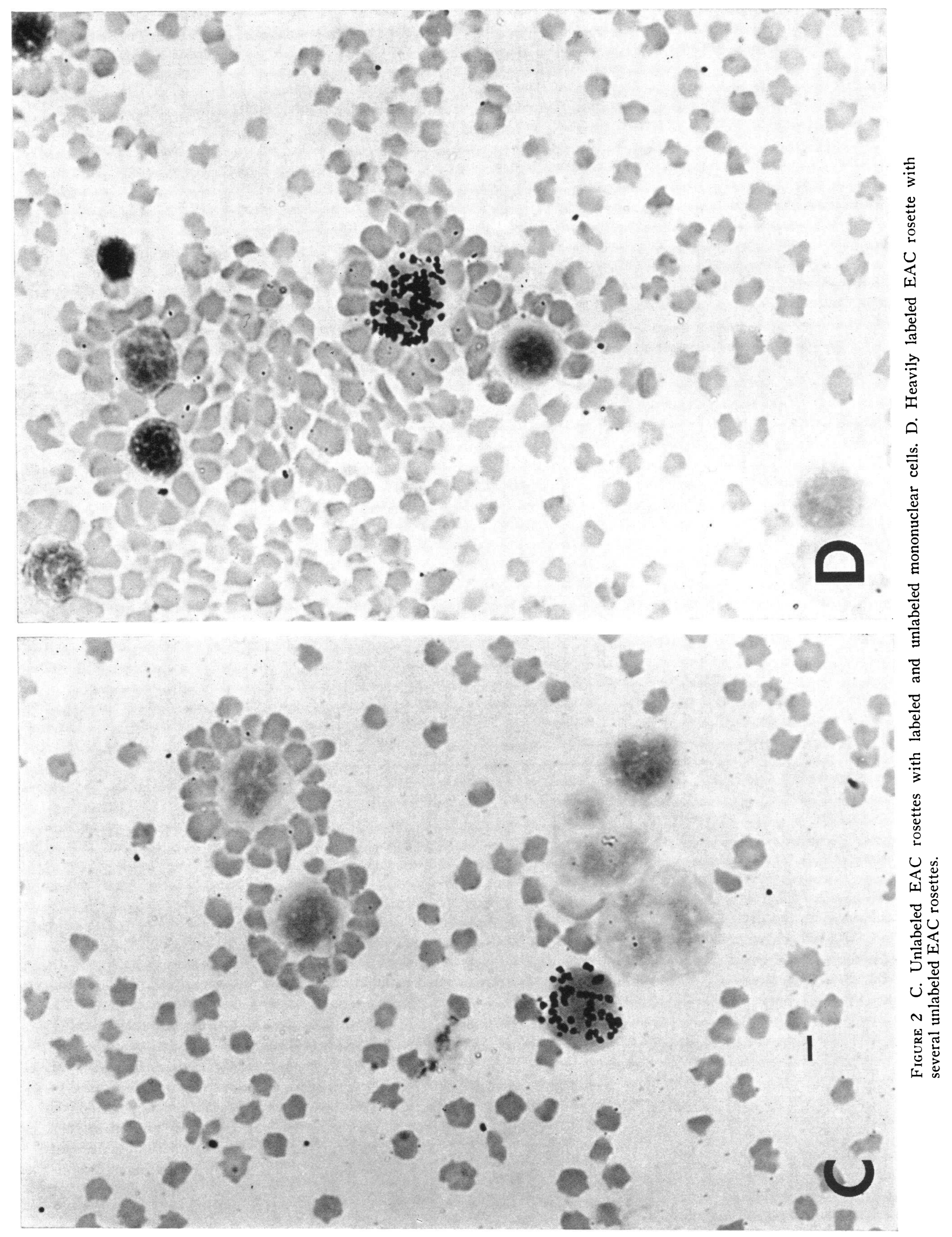




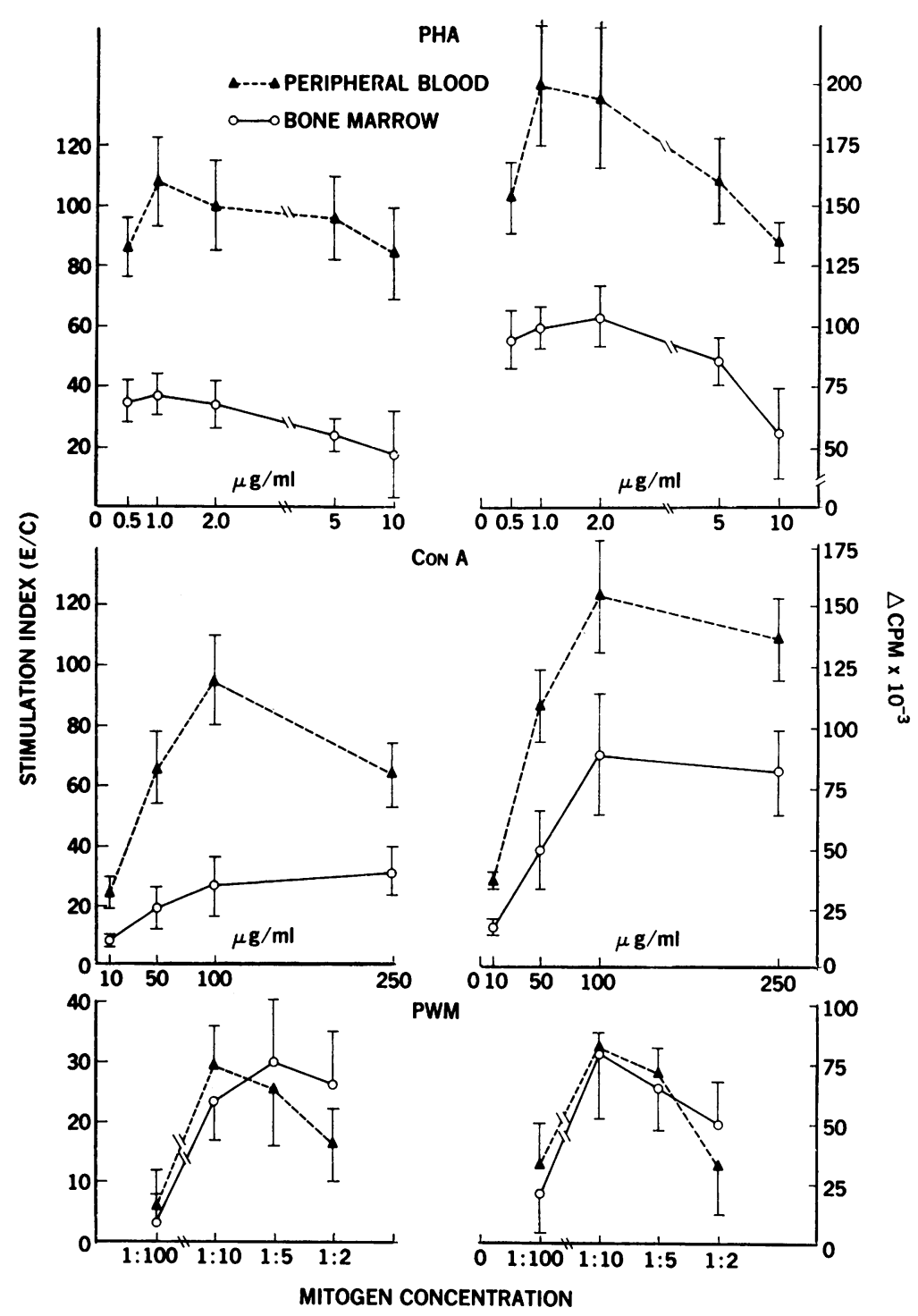

FIGURE 3 Relative blastogenic responses of peripheral blood and BM lymphocytes to PHA, Con A, and PWM. Points shown are the mean ( \pm SEM) responses in 15 subjects. Responses are expressed both as the stimulation index $(\mathrm{E} / \mathrm{C})$ and the $\Delta \mathrm{cpm}$.

the relative percentages of $\mathrm{E}$ and $\mathrm{EAC}$ rosettes in the $\mathrm{BM}$ and PB which were labeled. There is little difference in the percentage of labeled $\mathrm{E}$ rosettes in the $\mathrm{BM}$ and $\mathrm{PB}(P>0.2$, Student's $t$ test $)$ indicating that the proliferative capacity of these populations of lymphocytes whether in the $\mathrm{BM}$ or circulating in the $\mathrm{PB}$ is the same. On the other hand, EAC rosette-forming lymphocytes in the $B M$ have a greater potential for spontaneous proliferation than do their counterparts in the PB $(P<0.01)$. As mentioned above, no labeled small lymphocytes were seen, and so all labeled $E$ and $\mathrm{EAC}$ rosettes in the $\mathrm{BM}$ and $\mathrm{PB}$ were medium or large lymphocytes.
Mitogen induced blastogenic responses of $B M$ and $P B$ lymphocytes. Fig. 3 illustrates the relative responses of $\mathrm{BM}$ and $\mathrm{PB}$ lymphocytes of 15 subjects to in vitro stimulation with the mitogens PHA, Con $\mathrm{A}$, and PWM. Dose response curves demonstrate clear-cut responses of BM lymphocytes to all three mitogens whether the data are expressed as the stimulation index or $\Delta \mathrm{cpm}$. Of note is the fact that fractionation of $\mathrm{BM}$ lymphoid cells on sucrose gradients was essential to obtain such responses. Culture of unfractionated or Hypaque-Ficoll separated BM aspirates resulted in very poor responses to mitogens with stimulation indices of only 1-3 in most cases. In separate preliminary experi- 
ments, separation of $\mathrm{PB}$ lymphocytes by the sucrose gradient technique did not noticeably alter the responsiveness to mitogens as compared to HypaqueFicoll separated PB lymphocytes. Of interest is the fact that $\mathrm{PB}$ lymphocyte responses to $\mathrm{PHA}$ and Con $\mathrm{A}$ were noticeably much greater than $\mathrm{BM}$ lymphocyte responses, while BM lymphocyte responses to PWM were as great as those of $\mathrm{PB}$ lymphocytes.

To rule out the possibility that lymphocytes from the small amount of $\mathrm{PB}$ contaminating the $\mathrm{BM}$ aspirates were responsible for the mitogen responses seen with the $\mathrm{BM}$ aspirates, irradiated $\mathrm{BM}$ aspirates were mixed with equal volumes of nonirradiated $\mathrm{PB}$ in four subjects (cf. Methods), and PHA responses were determined. Fig. 4 illustrates that $\mathrm{PB}$ lymphocytes contaminating the $\mathrm{BM}$ aspirate had a small but definite response to PHA when diluted in the BM lymphocytes. However, this response is far less than that seen with nonirradiated $\mathrm{BM}$. Irradiated $\mathrm{BM}$ alone gave no response to PHA stimulation. Hence, the mitogen responses of $\mathrm{BM}$ aspirates seen in Fig. 3 may in part be explained by contaminating $\mathrm{PB}$. However, this cannot nearly explain the entire mitogen response of the BM sample.

\section{DISCUSSION}

It has been firmly established that there exists in the lymphocyte pool within the BM of normal animals a small fraction ( $10 \%$ or less) of long-lived, recirculating lymphocytes which presumably are mature $\mathrm{T}$ lymphocytes $(3,4,33)$. Their presence cannot be explained by blood within vascular channels in the BM, and they are contained within the BM parenchyma itself (3). These cells belong to a vastly larger total body recirculating lymphocyte pool which can migrate freely into and out of lymphoid compartments. A small fraction of these cells gain entrance to and take up normal residence in the $\operatorname{BM}(3,4)$.

The concept of the accessibility of the BM parenchyma to the traffic of recirculating mature $T$ lymphocytes is strengthened by the fact that manipulations such as corticosteroid administration which can alter the distribution of recirculating $\mathrm{T}$ lymphocytes results in an accumulation of these cells within the BM parenchyma (34-36). The demonstration of $\mathrm{T}$ cell function in $\mathrm{BM}$ cell suspensions is in keeping with the presence of a fraction of mature $T$ lymphocytes (7-13). The use of linear sucrose density gradients to obtain highly purified BM lymphoid cell suspensions (22) in animal studies has allowed for greatly improved investigations of BM lymphocyte populations. This technique has recently been applied to the study of human BM in certain immunodeficiency diseases $(15,37)$ and was used in the present studies to obtain purified mononuclear cell suspensions from BM with relative high cell yields.

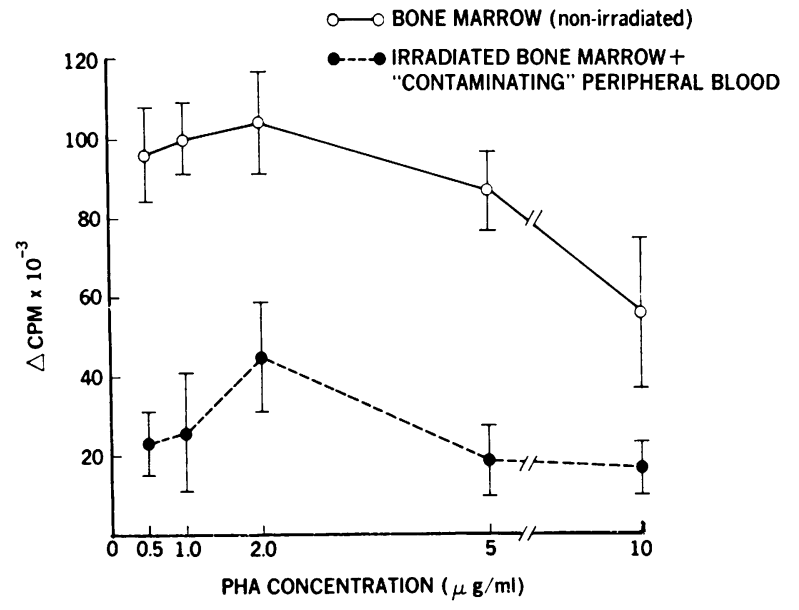

Figure 4 Effect of contaminating peripheral blood on PHA response of $\mathrm{BM}$. Irradiated BM was mixed with an equal volume of nonirradiated peripheral blood. Data compare PHA response of normal BM with PHA response contributed by "maximal contamination" of aspirate by peripheral blood.

Because of the conflicting data with regard to the presence of mature $\mathrm{T}$ cells within human BM (14-20), it was considered essential that elements of artifact be controlled as much as possible in the present investigation. For this reason, BM aspirates were performed on a relatively large number of normal young adult volunteers. In addition, in the characterization of the lymphocyte populations of human BM, it is of utmost importance that the role of $\mathrm{PB}$ contaminating the $\mathrm{BM}$ aspirate be taken into account. The ${ }^{51} \mathrm{Cr}$-labeled $\mathrm{RBC}$ studies demonstrated that despite meticulous care, considerable contamination by volume of $\mathrm{PB}$ occurs with every aspirate. Although the absolute number of lymphoid cells from the small volume of contaminating $P B$ is small when compared to the absolute number of lymphoid cells in the BM aspirate, this nevertheless may significantly alter the proportion of a lymphocyte population which is considered to be within the BM when the true proportion is very small to begin with. The simultaneous determination of surface markers of $\mathrm{PB}$ and $\mathrm{BM}$ lymphocytes in the present study has allowed us to determine and correct for the precise amount of maximal possible contamination of $\mathrm{BM}$ by $\mathrm{PB}$ lymphocytes. Hence, the corrected proportion of $8.6( \pm 1.7) \%$ for $\mathrm{E}$ rosettes and $15.4( \pm 1.9) \%$ for EAC rosettes in the BM of these particular subjects cannot be attributed to $\mathrm{PB}$ contamination. The percentage of $\mathrm{T}$ lymphocytes in the $\mathrm{BM}$ in this study is remarkably close to the figure of $8( \pm 5) \%$ of $\mathrm{BM}$ lymphocytes bearing surface T-cell markers in mouse studies in which BM cell suspensions were also obtained by sucrose gradient separations (38). 
In addition, the proportions of $\mathrm{T}$ and $\mathrm{B}$ lymphocytes, as well as lymphoid cells without detectable surface markers found in the BM of normal individuals (Table III), are quite similar to the data reported in BM studies of a group of children in long-term (3-8 yr) continuous remission from acute lymphoblastic leukemia (20). In contrast, our findings of $8.6 \% \mathrm{E}$ rosettes in $\mathrm{BM}$ is higher than the $0-2 \%$ reported in human studies in which bovine serum albumin gradient separations were used $(16,17)$.

Previous studies have shown that contrary to the $\mathrm{PB}$ in which there is a greater proportion of IgG-bearing lymphocytes than IgM-bearing lymphocytes, the reverse is true in BM, i.e., there is a significantly greater proportion of IgM-bearing lymphocytes $(20,37)$. This same pattern was noted in the present studies. The slight discrepancy between the proportion of Ig-bearing and EAC-rosetting lymphocytes in the BM may be explained by one or more of several factors including a lack of comparable sensitivity of the techniques used, the recognized difficulty in distinguishing lymphocyte from nonlymphocyte mononuclear cells in the BM, and the fact that lymphocytes in various stages of development may preferentially express or fail to express one or more of their potential markers (39).

In addition to a fraction of lymphocytes bearing surface $\mathrm{T}$-cell markers, a definite response to mitogenic stimulation was present in the BM lymphocyte fraction (Fig. 3). Of interest is the fact that there was a markedly greater responsiveness of $\mathrm{PB}$ lymphocytes to $\mathrm{PHA}$ and Con A than BM lymphocytes. Yet, the response of BM lymphocytes to PWM was proportionately greater than to PHA and Con A when compared with $\mathrm{PB}$ lymphocytes. In fact, the response of BM lymphocytes to PWM was equal to that of $\mathrm{PB}$ lymphocytes. These findings demonstrate: $(a)$ that there is a definite fraction of PHA and Con A responsive lymphocytes in the $\mathrm{BM}$ of normal individuals; and $(b)$ the population of $\mathrm{BM}$ lymphocytes responsive to PWM is proportionately greater than the population responsive to $\mathrm{PHA}$ and Con $\mathrm{A}$ when compared to $\mathrm{PB}$. Hence, functionally distinct subpopulations of lymphocytes as measured by differential response to mitogenic stimulation are present both in the PB and BM of normal individuals, but in measurably different proportions in the two compartments.

The problem of contaminating $\mathrm{PB}$ lymphocytes must always be considered in the evaluation of the mitogen responsiveness of $\mathrm{BM}$ lymphocytes. As shown, there is a small but definite fraction of BM lymphocytes bearing surface $T$ cell markers over and above those attributable to contaminating $\mathrm{PB}$. It is difficult to determine the relative contributions of $\mathrm{BM}$ lymphocytes and contaminating $\mathrm{PB}$ lymphocytes to the mitogen responsiveness of the fractionated $\mathrm{BM}$ aspirates shown in
Fig. 3. For this reason experiments were performed mixing nonirradiated $\mathrm{PB}$ with irradiated $\mathrm{BM}$ (Fig. 4). These studies clearly showed that although contaminating $\mathrm{PB}$ lymphocytes give a detectable $\mathrm{PHA}$ response, they are not sufficient to account for the PHA responsiveness of the BM lymphoid cells. One can reasonably assume that the PHA responsiveness of BM lymphocytes within the BM parenchyma is due to the small fraction of these cells bearing the surface $\mathrm{T}$-lymphocyte marker. However, it cannot be ruled out by the present techniques that other lymphocyte subpopulations which do not form $E$ rosettes are also contributing to the PHA responsiveness of the BM lymphoid cells.

Inasmuch as animal studies $(3,4,33)$ have shown that the $\mathrm{T}$ lymphocytes found in $\mathrm{BM}$ are long-lived recirculating lymphocytes which have entered the $B M$ parenchyma from the recirculating lymphocyte pool, one would expect the maturity and proliferative capacities of $\mathrm{T}$ lymphocytes in the $\mathrm{BM}$ and $\mathrm{PB}$ to be similar. Although it is extremely difficult by presently available techniques to accurately determine the relative states of functional maturation of lymphocyte subpopulations, an attempt was made to address the question of relative proliferative capacities by comparing the spontaneous DNA synthesis (28-30) of $\mathrm{T}$ and $\mathrm{B}$ lymphocytes in the $\mathrm{PB}$ and $\mathrm{BM}$. Thus, radioautographs after in vitro incubation with ${ }^{8} \mathrm{HTdR}$ were done on unfractionated $\mathrm{PB}$ and $\mathrm{BM}$, as well as simultaneous rosette radioautographs on fractionated $\mathrm{PB}$ and $\mathrm{BM}$ lymphocytes. In unfractionated $\mathrm{PB}$, no labeled cells of the granulocytic series were seen nor were labeled small lymphocytes seen. Labeling was limited to a small fraction of medium to large sized mononuclear or lymphoid cells. This is in close agreement with other labeling studies in human PB $(29,30)$. In unfractionated $\mathrm{BM}$, it was noted in the present experiments that after $1 \mathrm{~h}$ of in vitro incubation with ${ }^{3} \mathrm{HTdR}$, cells of all series were labeled. After fractionation of labeled BM lymphoid cells, $14.9( \pm 2.3) \%$ of the mononuclear cells were labeled. This figure is in close agreement with the proportion of guinea pig BM lymphoid cells labeled $1 \mathrm{~h}$ after in vivo administration of ${ }^{3} \mathrm{HTdR}$ (40).

The similarity in proliferative capacities between $T$ lymphocytes in the PB and BM (Table IV) is compatible with, but in no way proves that, the $\mathrm{T}$ lymphocytes in these compartments are from the same population. If, however, they are the same population of cells, this would be consistent with animal data which have shown that the $\mathrm{T}$ lymphocytes found in the BM parenchyma are part of the same recirculating pool of $T$ lymphocytes found in the $\operatorname{PB}(3,4,33)$. In addition, the relatively greater proportion of EAC-rosetting $B$ lymphocytes with proliferative capacity in the BM as compared to $\mathrm{PB}$ is compatible with the $\mathrm{BM}$ origin of 
these cells (1), as well as with the loss of a certain degree of proliferative potential as they leave the BM and enter the $\mathrm{PB}$. However, these data do not rule out the possibility that EAC-rosetting lymphocytes in the $\mathrm{PB}$ may be a distinct population of cells from the EACrosetting lymphocytes in the BM and may not result from a further maturation of these cells originally present in the BM.

Hence, these studies have shown that in addition to a B cell compartment, the normal human BM contains a small but definite fraction of $\mathrm{T}$ lymphocytes. These cells are probably part of the larger recirculating pool of mature $\mathrm{T}$ lymphocytes which have gained entrance to and reside normally in the BM. More precise characterization of lymphocyte subpopulations in the human BM will be essential to further understanding of various immunodeficiency diseases, such phenomena as the graft-versus-host reaction associated with BM transplantation, as well as compartmentalization of lymphocytes in certain disease states and during various chemotherapeutic regimens.

\section{ACKNOWLEDGMENTS}

The author thanks Mrs. Rhoda Hubert and Mrs. Karen Pratt for expert technical assistance. The gift of 19S EA from Dr. Michael M. Frank is gratefully acknowledged.

\section{REFERENCES}

1. Abdou, N. I., and M. Richter. 1970. The role of bone marrow in the immune response. Adv. Immunol. 12: 201-270.

2. Wu, A. M., J. E. Till, L. Siminovitch, and E. A. McCulloch. 1968. Cytological evidence for a relationship between normal hematopoietic colony-forming cells and cells of the lymphoid system. J. Exp. Med. 127: 455$464+$ plates 61 and 62 .

3. Rosse, C. 1972. Migration of long-lived lymphocytes to the bone marrow and to other lymphomyeloid tissues in normal parabiotic guinea pigs. Blood J. Hematol. 40: 90-97.

4. Röpke, C., and N. B. Everett. 1974. Migration of small lymphocytes in adult mice demonstrated by parabiosis. Cell Tissue Kinet. 7: 137-150.

5. Gowans, J. L., and E. J. Knight. 1964. The route of recirculation of lymphocytes in the rat. Proc. $R$. Soc. Lond. B Biol. Sci. 159: 257-282.

6. Ford, W. L., and J. L. Gowans. 1969. The traffic of lymphocytes. Semin. Hematol. 6: 67-83.

7. Osmond, D. G. 1968. Culture of lymphocyte-rich fractions of bone marrow with phytohemagglutinin and pokeweed mitogen. Anat. Rec. 160: 403. (Abstr.).

8. Claman, H. N. 1974. Bone marrow T cells. I. Response to the $\mathrm{T}$ cell mitogens, phytohemagglutinin, and concanavalin A. J. Immunol. 112: 960-964.

9. Singhal, S. K., and M. Richter. 1968. Cells involved in the immune response. IV. The response of normal and immune rabbit bone marrow and lymphoid tissue lymphocytes to antigens in vitro. J. Exp. Med. 128: 1099-1128.
10. Yoshida, Y., and D. G. Osmond. 1971. Blastogenic response of lymphocytes separated from bone marrow to allogeneic lymphoid cells in vitro. Immunology. 21: 767-779.

11. Asherson, G. L., M. Zembala, and B. Mayhew. 1974. Passive transfer of contact sensitivity by bone marrow cells and evidence for their origin from immunized lymph nodes. Int. Arch. Allergy Appl. Immunol. 46: 256-260.

12. Cohen, J. J., and H. N. Claman. 1971. Hydrocortisone resistance of activated initiator cells in graft versus host reactions. Nature (Lond.). 229: 274-275.

13. Chen, M. G., G. B. Price; and T. Makinodan. 1972. Incidence of delayed mortality (secondary disease) in allogeneic radiation chimeras receiving bone marrow from aged mice. J. Immunol. 108: 1370-1378.

14. Pegrum, G. D., D. Ready, and E. Thompson. 1968. The in vitro effect of phytohaemagglutinin on separated human bone marrow cells. Br. J. Haematol. 15: 377-380.

15. Abdou, N. I., and N. L. Abdou. 1972. Bone marrow: the bursa equivalent in man? Science (Wash. D. C.). 175 : 446-448.

16. Touraine, J. L., G. S. Incefy, F. Touraine, Y. M. Rho, and R. A. Good. 1974. Differentiation of human bone marrow cells into $\mathrm{T}$ lymphocytes by in vitro incubation with thymic extracts. Clin. Exp. Immunol. 17: 151-158.

17. Geha, R. S., J. G. Gatien, R. Parkman, J. D. Crain, F. S. Rosen, and E. Merler. 1974. Discontinuous density gradient analysis of human bone marrow: presence of alloantigen-responsive, PHA-unresponsive cells in normal bone marrow, absence of $B$ lymphocytes in the bone marrow of patients with X-linked agammaglobulinemia. Clin. Immunol. Immunopathol. 2: 404-415.

18. Borella, L., and A. A. Green. 1972. Sequestration of PHA-responsive cells ( $\mathrm{T}$-lymphocytes) in the bone marrow of leukemic children undergoing long-term immunosuppressive therapy. J. Immunol. 109: 927-932.

19. Borella, L., and L. Sen. 1973. T cell surface markers on lymphoblasts from acute lymphocytic leukemia. J. Immunol. 111 : 1257-1260.

20. Borella, L., and L. Sen. 1974. The distribution of lymphocytes with $\mathrm{T}$ - and B-cell surface markers in human bone marrow. J. Immunol. 112: 836-843.

21. Donahue, D. M., B. W. Gabrio, and C. A. Finch. 1958. Quantitative measurement of hematopoietic cells of the marrow. J. Clin. Invest. 37: 1564-1570.

22. Osmond, D. G. 1967. The separation of lymphocytes from bone marrow by centrifugation in a density gradient. Anat. Rec. 157: 295. (Abstr.).

23. Böyum, A. 1968. Isolation of mononuclear cells and granulocytes from human blood. Isolation of mononuclear cells by one centrifugation, and of granulocytes by combining centrifugation and sedimentation at $1 \mathrm{~g}$. Scand. J. Clin. Lab. Invest. 21 (Suppl. 97) : 77-89.

24. Jondal, M., G. Holm, and H. Wigzell. 1972. Surface markers on human $\mathrm{T}$ and $\mathrm{B}$ lymphocytes. I. A large population of lymphocytes forming nonimmune rosettes with sheep red blood cells. J. Exp. Med. 136: 207-215.

25. Bianco, C., R. Patrick, and V. Nussenzweig. 1970. A population of lymphocytes bearing a membrane receptor for antigen-antibody-complement complexes. I. Separation and characterization. J. Exp. Med. 132: 702-720.

26. Frank, M. M., and T. Gaither. 1970. The effect of temperature on the reactivity of guinea pig complement with IgG and IgM haemolytic antibodies. Immunology. 19: 967-974.

Human Bone Marrow Lymphocytes 109 
27. Papamichail, M., J. C. Brown, and E. J. Holborow. 1971. Immunoglobulins on the surface of human lymphocytes. Lancet. 2: 850-852.

28. Cronkite, E. P., V. P. Bond, T. M. Fliedner, and J. R. Rubini. 1959. Tritiated thymidine in the study of deoxyribonucleic acid synthesis and cell turnover in hematopoietic tissues. Lab. Invest. 8: 263-277.

29. Bond, V. P., E. P. Cronkite, T. M. Fliedner, and P. Schork. 1958. Deoxyribonucleic acid synthesizing cells in peripheral blood of normal human beings. Science (Wash. D. C.). 128: 202-203.

30. Cronkite, E. P., T. M. Fliedner, V. P. Bond, J. R. Rubini, G. Brecker, and H. Quastler. 1959. Dynamics of hemopoietic proliferation in man and mice studied by ${ }^{3} \mathrm{H}$-thymidine incorporation into DNA. Ann. N. Y. Acad. Sci. 77: 803-820.

31. Fauci, A. S., and D. C. Dale. 1975. Alternate-day prednisone therapy and human lymphocyte subpopulations. J. Clin. Invest. $55:$ 22-32.

32. Dixon, W. J., and F. J. Massey, Jr. 1969. Introduction to Statistical Analysis. McGraw-Hill Book Co., New York. 3rd edition. 116.

33. Haas, R. J., F. Bohne, and T. M. Fliedner. 1969. On the development of slowly-turning-over cell types in neonatal rat bone marrow. Studies utilizing the complete tritiated thymidine labeling method completed by C-14 thymidine administration. Blood J. Hematol. 34: 791805.
34. Levine, M. A., and H. N. Claman. 1970. Bone marrow and spleen: dissociation of immunologic properties by cortisone. Science (Wash. D. C.). 167: 1515-1517.

35. Cohen, J. J. 1972. Thymus-derived lymphocytes sequestered in the bone marrow of hydrocortisone-treated mice. J. Immunol. 108: 841-844.

36. Fauci, A. S. 1975. Mechanisms of corticosteroid action on lymphocyte subpopulations. I. Redistribution of circulating $\mathrm{T}$ and $\mathrm{B}$ lymphocytes to the bone marrow. Immunology. 28: 669-680.

37. Abdou, N. I., S. R. Casella, N. L. Abdou, and I. A. Abrahamsohn. 1973. Comparative study of bone marrow and blood B cells in infantile and acquired agammaglobulinemia. Possible role of circulating anti-IgM in pathogenesis. J. Clin. Invest. 52: 2218-2224.

38. Ryser, J.-E., and P. Vassalli. 1974. Mouse bone marrow lymphocytes and their differentiation. J. Immunol. 113: 719-728.

39. Jondal, M., H. Wigzell, and F. Aiuti. 1973. Human lymphocyte subpopulations: classification according to surface markers and/or functional characteristics. Transplant. Rev. 16: 163-195.

40. Osmond, D. G., S. C. Miller, and Y. Yoshida. 1973. Kinetic and haemopoietic properties of lymphoid cells in the bone marrow. In Haemopoietic Stem Cells. Ciba Foundation Symposium 13. Associated Scientific Publishers, New York. 130-156. 